Виі. 1, 2019

УДК 621.316.925

В. І. Ткачук

Національний університет “Львівська політехніка", кафедра електромехатроніки та комп'ютеризованих електромеханічних систем, tkachuk@polynet.lviv.ua,

І. Є. Біляковський

Національний університет “Львівська політехніка”, кафедра електромехатроніки та комп’ютеризованих електромеханічних систем, ibilyakovsky@gmail.com,

Л. В. Каша

Національний університет “Львівська політехніка", кафедра електромехатроніки та комп’ютеризованих електромеханічних систем, lidiia.v.kasha@lpnu.ua

\title{
ВЕНТИЛЬНИЙ РЕАКТИВНИЙ ДВИГУН ІЗ БУФЕРОМ ЕНЕРГІЇ У СИСТЕМАХ ІЗ АВТОНОМНИМ ЖИВЛЕННЯМ ОБМЕЖЕНОЇ ПОТУЖНОСТІ
}

https://doi.org/10.23939/sepes2019.01.054

(C) Ткачук В. І., Біляковський I. С., Кама Л. В., 2019

Обгрунтовано доцільність використання ємнісного нагромаджувача в колі електронного комутатора для покращення техніко-економічних показників вентильних реактивних двигунів. Такий електромеханічний перетворювач максимально простий конструктивно, дешевий у виготовленні та має хороші технологічні характеристики порівняно із найпростішими електричними машинами - асинхронними, а привід на базі вентильного двигуна 3 пасивним ротором за регулювальними властивостями не поступається приводам 3 колекторними двигунами постійного струму, які набули необмеженого поширення.

Запропоновано нові електричні схемні рішення, оріснтовані на живлення від джерел низької напруги й обмеженої потужності з використанням буферів енергї, які здійснюють захист силових ключів комутатора від перенапруги під час вимкнення секції та виконують функцію акумулювання запасеної в магнітному полі енергії, яку потім використано для форсування струму секції. Організовувати керування у таких схемах електронного комутатора можна логічним перемноженням певних сигналів давача положення ротора для формування сигналів керування.

Наведену в матеріалах математичну модель, використану для дослідження, реалізовано для миттєвих значень вентильного реактивного двигуна 3 ємнісними буферами енергії, вона слугує основою для розрахунку його характеристик. Для того щоб вирішити проблему відшукання моментів комутації у задачах такого типу, використано метод інвертування нелінійної системи диференціальних рівнянь. Метод 
Вентильний реактивний двигун із буфером енергї в системах з автономним живленням...

полягає у виборі незалежною змінною кута комутації за перемикання якогось із силових ключів електронного комутатора. Дослідження механічних та робочих характеристик вентильного двигуна із пасивним ротором та буфером енергії здійснено в середовищі комп'ютерної програми дослідження вентильних реактивних двигунів із буферами енергіï.

Наведено приклади розрахунку динамічних та статичних характеристик двигунів. Результати комп'ютерного симулювання електромеханічних процесів підтверджені експериментальними дослідженнями та свідчать про адекватність наведеної у матеріалах математичної моделі та доцільність відповідного використання такого типу двигуна.

Ключові слова: вентильний реактивний двигун; пасивний ротор; транзисторні ключі; джерело низької напруги; ємнісний буфер енергї̈; математична модель.

\section{Постановка проблеми}

Вентильні двигуни постійного струму є електричними машинами, у яких щітково-колекторний вузол замінено транзисторним комутатором - інвертором, який керується сигналами $f$ ( $\square$ від давача положення ротора (ДПР)).

Одним із найпростіших за конструкцією, технологічним та 3 високими показниками надійності є електромеханічний перетворювач (ЕМП) з явнополюсним статором, зосередженими котушками його обмотки та зубчастим пасивним ротором [1]. Такий ЕМП конструктивно максимально простий, дешевий у виготовленні та має хороші технологічні характеристики порівняно із найпростішими електричними машинами - асинхронними, а привід на основі вентильного двигуна (ВД) із пасивним ротором за регулювальними властивостями не поступається приводам із колекторними двигунами постійного струму, які набули необмеженого поширення. Велика низка публікацій у зарубіжній технічній періодиці висвітлює власне дослідження двигунів такого типу [2-4]. Окрім цього, вітчизняні підприємства електротехнічної галузі звертають підвищену увагу на ВД з пасивним ротором, а це свідчить про швидке зростання популярності вентильних реактивних двигунів (ВРД) [6]. Технологічність і простота конструкції, дешевизна та стійкість у роботі, задовільні регулювальні характеристики зумовили розширене використання цих електричних машин в електроприводі, де необхідні високі споживчі показники. Найпростіше описати ВД можна визначенням, що це електромеханічний перетворювач (ЕМП) + давач положення ротора (ДПР) + електронний перетворювач (ЕП).

Однак широке використання реактивних вентильних двигунів стримується їх невисокими енергетичними показниками $[1,4,7]$, оскільки енергія, яка запасена в електромагнітному полі під час комутації в секціях транзисторними ключами з метою захисту їх від перенапруг, розсіюється під час комутації секцій.

\section{Актуальність дослідження}

Типові методи підвищення ефективності використання двигунів, які грунтуються на збільшенні електромагнітних навантажень [3, 7], у випадку з ВРД призводять до зростання пульсацій споживаного струму, а це обмежує їх використанням за живлення від малопотужних джерел у регульованих електроприводах обмеженої потужності [5]. Тому актуальним видається розроблення нових схем комутаторів та удосконалення наявних і розроблення нових математичних моделей ВД.

\section{Мета та завдання статті}

Мета статті - розроблення схемних рішень електронних комутаторів, які б забезпечували підвищення надійності та покращення енергетичних показників, зменшували пульсації струму джерела живлення ВД із пасивним ротором за допомогою модернізації схем транзисторних комутаторів, а також удосконалення розроблених математичної та комп'ютерної моделей вентильного реактивного двигуна з паралельним ємнісним накопичувачем. 


\section{Аналіз останніх досліджень і публікацій}

3 усього різноманіття конструкцій ЕМП $[2,3,5]$ найбільший інтерес для застосування їх у ВД становлять ЕМП із пасивними роторами [1]. Вони прості у виготовленні, не потребують налаштувань, надійні в експлуатації [5].

Схемні рішення транзисторних інверторів ВРД [2, 4], які дають змогу повторно використовувати запасену в електромагнітному полі енергію, підвищуючи початковий струм у секціях та усуваючи перевищення напруги на силових транзисторах, запропоновано в [6]. Це дало змогу підвищити ефективність і регулювальні властивості приводів на базі вентильного двигуна 3 пасивним ротором до рівня приводів з колекторними двигунами постійного струму.

\section{Виклад основного матеріалу}

Для покращення енергетичних показників, а разом з тим, і зменшення пульсацій струму, зокрема, у випадку живлення від автономного джерела обмеженої потужності, запропоновано використовувати однопівперіодний комутатор із паралельно під'єднаним нагромаджувальним конденсатором - паралельним буфером енергії (ПБЕ), інакше - ємнісним накопичувачем енергії (СНЕ) [6].

Поряд із цим, для зменшення втрат на ключах комутатора, частка яких зростає зі зниженням напруги джерела живлення, необхідно вибрати електронні компоненти із мінімальним спадом напруги у відкритому стані.

Комутатор із паралельним буфером енергії та окремими підживлювальними ключами.

На рис. 1 показано електричну схему ВРД із буфером енергії.

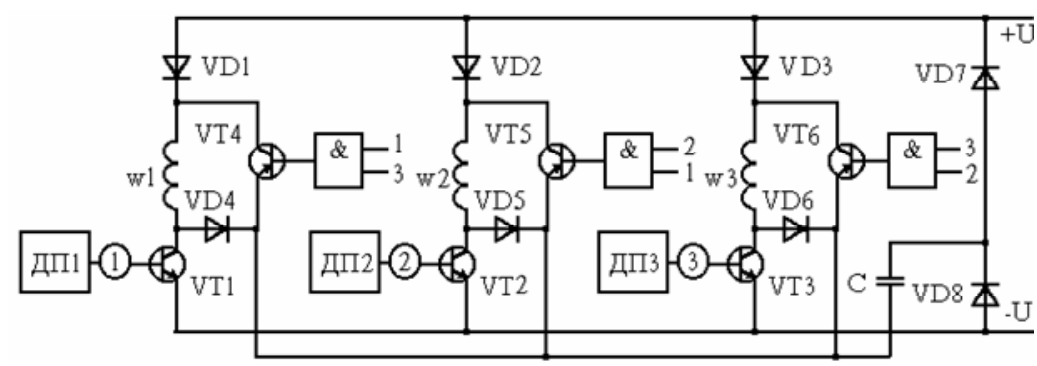

Рис. 1. Транзисторний комутатор із паралельним буфером енергії

Комутатор із паралельним буфером енергії та спільним підживлювальним ключем.

Підвищити надійність ВД із паралельним ємнісним накопичувачем енергії можна, застосувавши схему, наведену на рис. 2.

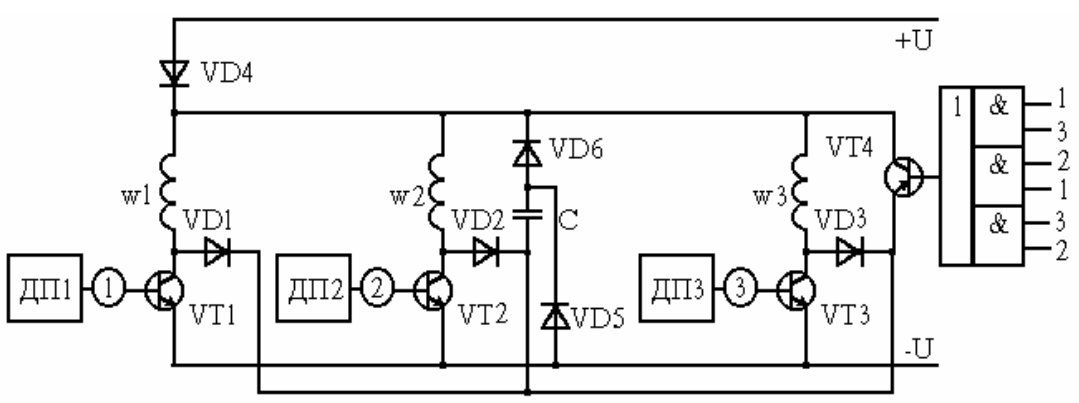

Рис. 2. ВРД із паралельним буфером й спільним колом форсування

У цій схемі керування ключем VT4 здійснюється аналогічно до попереднього випадку, сигналом зі схеми встановлення збігу сигналів суміжних каналів ДПР [6]. За деякого положення ротора одночасно відкриваються один із силових ключів і підживлювальний ключ VT4.

Напруга конденсатора прикладається до двох секцій якірної обмотки (діод VD4 буде закритий напругою на конденсаторі, яка вища від напруги живлення). Конденсатор розряджається і після 
того, як напруга на ньому дорівнюватиме напрузі живлення, секції надалі будуть приєднані до джерела живлення через відкритий тепер діод VD4.

Рис. 3. Діаграма роботи силових ключів, напруга конденсатора та струм секиії ВРД з ПБЕ

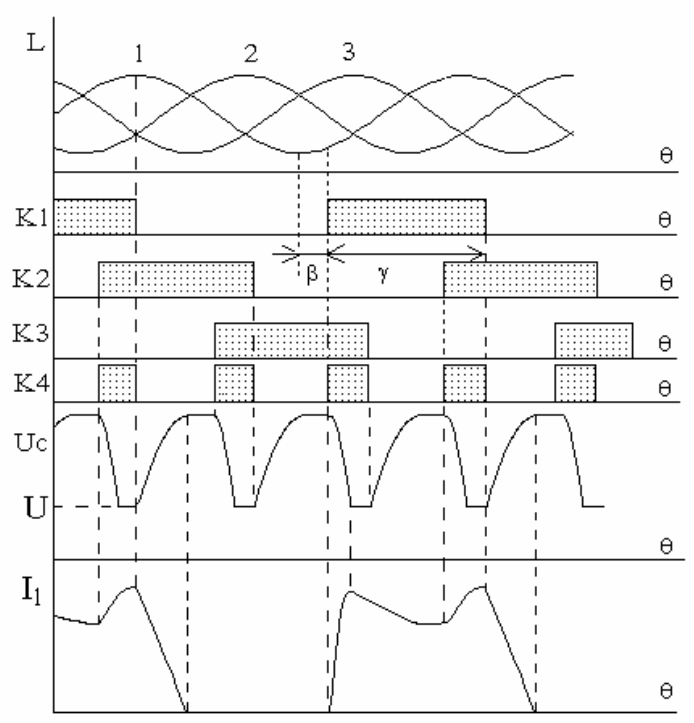

\section{Математична модель ВРД із паралельним смнісним накопичувачем}

Для побудови математичної моделі вентильного двигуна 3 урахуванням наведеного вище приймемо допущення [7], [8], які не надто спотворювали б реальні фізичні процеси i, за порівняно нескладних математичних виразів для основних величин, адекватно відображали б перетворення енергіï.

Основні $з$ них такі:

- внутрішній опір джерела напруги інвертора дорівнює нулю;

- між секціями обмотки двигуна відсутні магнітні зв'язки;

- силові транзистори комутатора - електронні ключі, які комутують секції ВРД практично миттєво;

- значення зворотного опору закритого ключа прямує до нескінченності;

- магнітна характеристика магнітопроводу магнітоізольованої секції подана виразом [3]

$$
\psi(\theta, i)=\left[\psi_{10}-\psi_{1 t} \cdot \operatorname{Sin}(\theta / 2)\right] \cdot i+\psi_{y} \cdot \operatorname{Sin}(\theta / 2) \cdot\left[1-e^{-a \cdot i \cdot \operatorname{Sin}(\theta / 2)}\right] ;
$$

- параметри обмотки статора зосереджені.

Змінний магнітний потік, замикаючись по магнітопроводу, спричиняє втрати від вихрових струмів, опір сталі яким визначається за виразом

$$
R_{s}=\frac{E^{2}}{\Delta P_{s}},
$$

де $E=4.44 \cdot f \cdot w_{z} \cdot B \cdot s$ і $\Delta P_{s}=P_{0} \cdot \gamma_{s} \cdot s \cdot l_{M} \cdot B^{2} \cdot\left(f / f_{0}\right)^{2}$, звідки отримаємо вираз для обчислення $R_{s}$ однієї секції:

$$
R_{s}=4,9 \cdot 10^{4} \cdot \frac{w_{z}^{2} \cdot S \cdot q}{p_{0} \cdot \gamma_{s} \cdot l_{m}}
$$

де $p_{0}, \gamma_{\mathrm{s}}, \mathrm{S}, 1_{\mathrm{m}}, \mathrm{w}_{\mathrm{z}}, \mathrm{q}$ - відповідно, питомі втрати в сталі, iї густина, довжина силової лінії, значення витків обмотки на зубці та кількість зубців на одну секцію статора.

Згідно із прийнятими допущеннями, в електричному плані секції $m$-секційного ВРД розглядають окремо, а структура схеми під'єднання секції та рівняння напруг дискретно змінюватимуться у разі зміни кута $\gamma$ : 
1. Ключі VT1 й VT4 увімкнені, конденсатор $C$ заряджений. Секція $w 1$ живиться енергією конденсатора:

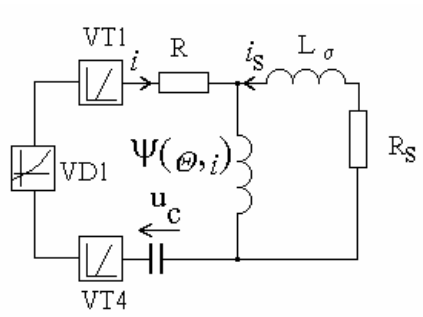

$$
\left\{\begin{array}{l}
R \cdot i+2 \cdot \Delta U_{T}+\Delta U_{\text {Д }}+\frac{d \psi(\theta, i)}{d t}=u_{c} \\
C \frac{d u_{c}}{d t}=i \\
R_{s} \cdot i_{s}+L_{\sigma} \cdot \frac{d i_{s}}{d t}+\frac{d \psi(\theta, i)}{d t}=0
\end{array}\right.
$$

2. Увімкнений транзисторний ключ $V T 1$, розряджений конденсатор $C$. Секція $w 1$ через цей ключ живиться від джерела:

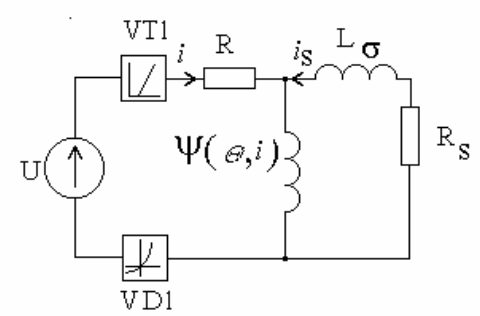

$$
\left\{\begin{array}{l}
R \cdot i+\Delta U_{\text {д }}+\Delta U_{T}+\frac{d \psi(\theta, i)}{d t}=U \\
R_{s} \cdot i_{s}+L_{\sigma} \cdot \frac{d i_{s}}{d t}+\frac{d \psi(\theta, i)}{d t}=0
\end{array}\right.
$$

3. Розімкнені ключі VT1 й VT4. Заряджається конденсатор:

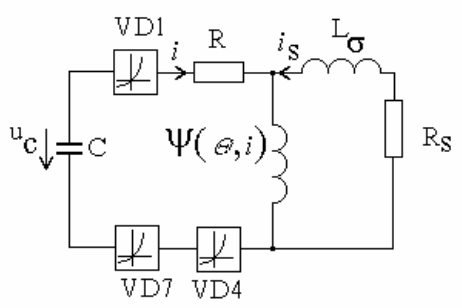

$$
\left\{\begin{array}{l}
R \cdot i+3 \cdot \Delta U_{\text {д }}+\frac{d \psi(\theta, i)}{d t}=-u_{c} \\
C \frac{d u_{c}}{d t}=-i \\
R_{s} \cdot i_{s}+L_{\sigma} \cdot \frac{d i_{s}}{d t}+\frac{d \psi(\theta, i)}{d t}=0
\end{array}\right.
$$

Коефіцієнти $K 1$ та $K 2$ уможливлюють узагальнений запис систем нелінійних диференціальних рівнянь (СНДР) (1), (2), (3):

$$
\left\{\begin{array}{l}
R \cdot i+\frac{d \psi(\theta, i)}{d t}=\left(U+\Delta U_{\text {Д }}\right) \cdot(K 1-K 2)+u_{c}(K 1+K 2-1)- \\
-\Delta U_{T}(K 1+K 2)-\Delta U_{\text {Д }}(3-K 1-K 2) \\
C \frac{d u_{c}}{d t}=i(1-K 1-K 2) \\
R_{s} \cdot i_{s}+L_{\sigma} \cdot \frac{d i_{s}}{d t}+\frac{d \psi(\theta, i)}{d t}=0
\end{array}\right.
$$

Вольт-амперна характеристика насиченого транзистора описується виразом

$$
\Delta U_{T}=U_{K E}=U_{K E .0}+R_{K E . H A C} \cdot i,
$$

де $U_{K E .0}$ i $R_{K E . H A C}$ визначають із паспорта на транзистор.

Стан транзисторних ключів ЕК описують формальні коефіцієнти, значення яких залежать від положення ротора, їх обчислюють згідно із такою перемикальною функцією:

$$
\begin{aligned}
& K_{j}=1 \text { якщо } \beta+2 \cdot\left(\mathrm{N}_{\mathrm{j}}-1\right) \cdot \pi+(j-1) \cdot 2 \cdot \frac{\pi}{m}\left\langle\theta \leq \beta+2 \cdot\left(\mathrm{N}_{\mathrm{j}}-1\right) \cdot \pi+(j-1) \cdot 2 \cdot \frac{\pi}{m}+\gamma\right. \\
& K_{j}=0 \text { для всіх інших значень, }
\end{aligned}
$$

де $N_{j}=\frac{\theta+\pi+(j-1) \cdot 2 \cdot \frac{\pi}{m}}{2 \cdot \pi}+1-$ номер періоду для відповідної секції, але якщо $u_{c}=0$, то і $\kappa 2=0$. 
Вентильний реактивний двигун із буфером енергї в системах з автономним живленням...

Враховуючи принцип роботи ВРД та згідно з [8]

$$
K_{j+m}=K_{j} \cdot K_{i}
$$

де $i=m-l+j$, якщо $2 \cdot(l+1) \cdot \pi / m \geq \gamma \geq 2 \cdot l \cdot \pi / m, l=1,2,3,4$; але $i=i-m$, коли $i>m$.

$$
K_{m+1}=\sum_{j=1}^{m} K_{j} \cdot K_{i}
$$

Математична модель ВРД із паралельним буфером енергії

Враховуючи вищенаведене, СНДР, яка описує електромеханічні процеси у ВРД із паралельним ЄHЕ, можна подати у вигляді:

$$
\begin{aligned}
& \frac{d i_{j}}{d t}=\left[u_{j}+R \cdot i_{j}+\frac{A_{j}}{L_{\sigma}} \cdot\left(u_{j}-R \cdot i_{j}+R_{s} \cdot i_{s j}\right)-B_{j} \cdot \omega\right] / A_{j} ; \\
& \frac{d i_{s j}}{d t}=-\left(R_{s} \cdot i_{s j}+u_{j}-R \cdot i_{j}\right) / L_{\sigma} \text {; } \\
& \frac{d u_{c j}}{d t}=\left(1-K_{j}-K_{j+m}\right) \cdot \frac{i_{j}}{C} \\
& \frac{d \omega}{d t}=\left\{\sum_{j=1}^{m}\left[\frac{z_{r}}{2} \cdot\left(i_{j}+i_{s j}\right) \cdot \operatorname{Cos} \theta_{p j} \cdot \psi_{y} \cdot\left(1-e^{-a \cdot\left(i_{j}+i_{s j}\right) \cdot \sin \theta_{p j}}-\frac{\psi_{1 t} \cdot\left(i_{j}+i_{s j}\right)}{2 \cdot \psi_{y}}\right)\right]-M_{C}\right\} \cdot \frac{z_{r}}{J} ; \\
& \frac{d \theta}{d t}=\omega ; \\
& \text { de } \mathrm{u}_{\mathrm{j}}=\left(U+\Delta U_{\text {д }}\right) \cdot\left(K_{j}-K_{j+m}\right)+u_{c} \cdot\left(K_{j}+K_{j+m}-1\right)- \\
& -\Delta U_{T} \cdot\left(K_{j}+K_{j+m}\right)-\Delta U_{\text {д }} \cdot\left(3-K_{j}-K_{j+m}\right) \text {; } \\
& \mathrm{A}_{\mathrm{j}}=\psi_{10}-\psi_{1 t} \cdot \operatorname{Sin} \theta_{p j}+\psi_{y} \cdot a \cdot \operatorname{Sin}^{2} \theta_{p j} \cdot e^{-a \cdot\left(i_{j}+i_{s j}\right) \cdot \operatorname{Sin} \theta_{p j}} ; \\
& \mathrm{B}_{\mathrm{j}}=\frac{\operatorname{Cos} \theta_{p j}}{2} \cdot\left[\begin{array}{l}
\psi_{y}-\psi_{1 t} \cdot\left(i_{j}+i_{s j}\right)-\psi_{y} \cdot e^{-a \cdot\left(i_{j}+i_{s j}\right) \cdot \operatorname{Sin} \theta_{p j}} \cdot \\
\cdot\left(1-a \cdot\left(i_{j}+i_{s j}\right) \cdot \operatorname{Sin} \theta_{p j}\right)
\end{array}\right] ; \\
& \theta_{\mathrm{pj}}=\frac{\theta}{2}-(j-1) \cdot \frac{2 \cdot \pi}{m} ;
\end{aligned}
$$

Для розв'язання СНДР (7) застосовано метод Рунге-Кутта четвертого порядку зі сталим кроком інтегрування [9].

Вирішення проблеми пошуку моментів комутації методом інвертування СНДР наведено в [6]: крок інтегрування визначають як різницю відомого значення кута $\theta$, за якого зміниться стан ключа, та знайденого на попередньому кроці значення $\theta$ (рис. 4).

НСДР, яка описує зміну змінних у функції кута $\theta$, отримуємо, користуючись правилом диференціювання складних функцій:

$$
\begin{gathered}
\frac{d i_{j}}{d \theta}=\frac{d i_{j}}{d t} \cdot \frac{d t}{d \theta} ; \quad \frac{\mathrm{d} i_{\mathrm{sj}}}{\mathrm{d} \theta}=\frac{\mathrm{di} i_{\mathrm{sj}}}{\mathrm{dt}} \cdot \frac{\mathrm{dt}}{d \theta} ; \quad \frac{\mathrm{du} \mathrm{cj}_{\mathrm{cj}}}{\mathrm{d} \theta}=\frac{\mathrm{du} \mathrm{cj}_{\mathrm{j}}}{\mathrm{dt}} \cdot \frac{\mathrm{dt}}{d \theta} ; \\
\frac{\mathrm{d} \omega}{\mathrm{d} \theta}=\frac{d \omega}{d t} \cdot \frac{d t}{d \theta} ; \quad \frac{\mathrm{d} t}{\mathrm{~d} \theta}=\frac{1}{\omega} ; \quad \frac{\mathrm{d} \theta}{\mathrm{d} \theta}=1 .
\end{gathered}
$$

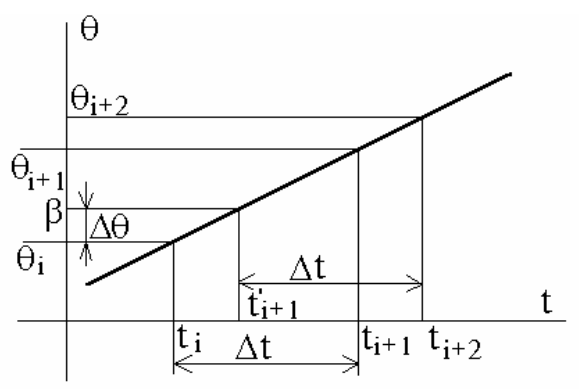

Рис. 4. До способу інвертування СНДР 
Похідні $\frac{d i_{j}}{d t}, \frac{d u_{c j}}{d t}, \frac{d \omega}{d t}$, які входять у наведені рівняння, обчислюють за (7).

Процес інтегрування за кутом $\theta$ аналогічний, як і за часом.

Результати комп'ютерного симулювання електромеханічних процесів у ВРД з На рис. 5-7 наведено струми секцій та напругу на конденсаторі для ВРД з СНЕ.

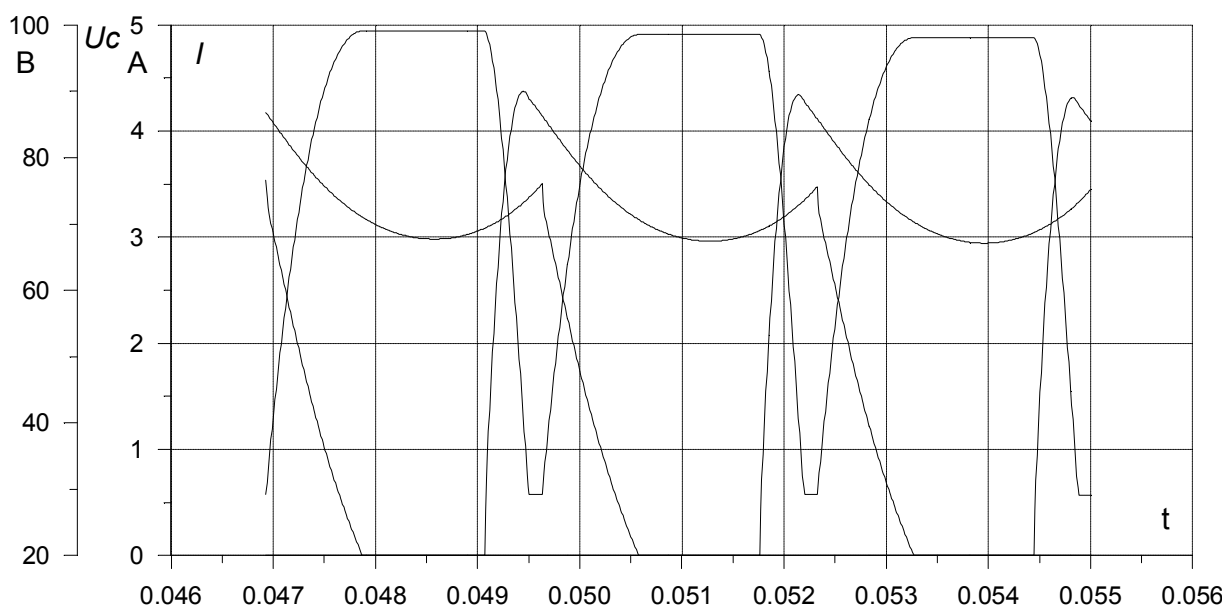

Рис. 5. Розрахункові струми секцій та напруга на конденсаторі ВРД з СНЕ

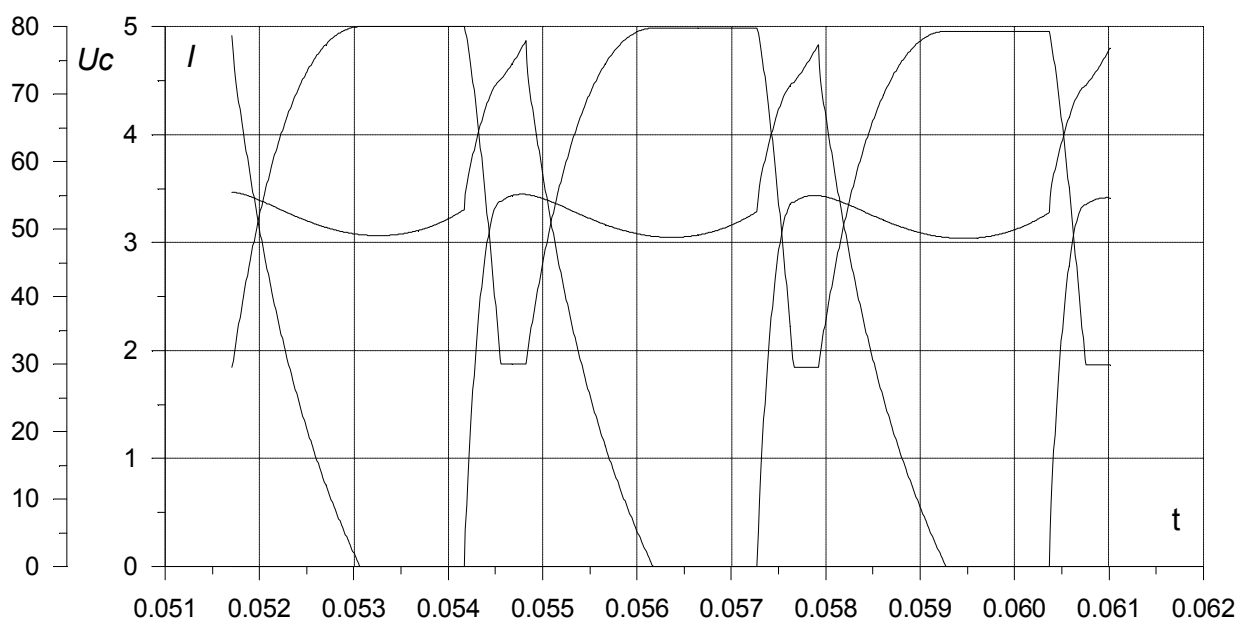

Рис. 6. Розрахункові струми секиій та напруга на конденсаторі ВРД

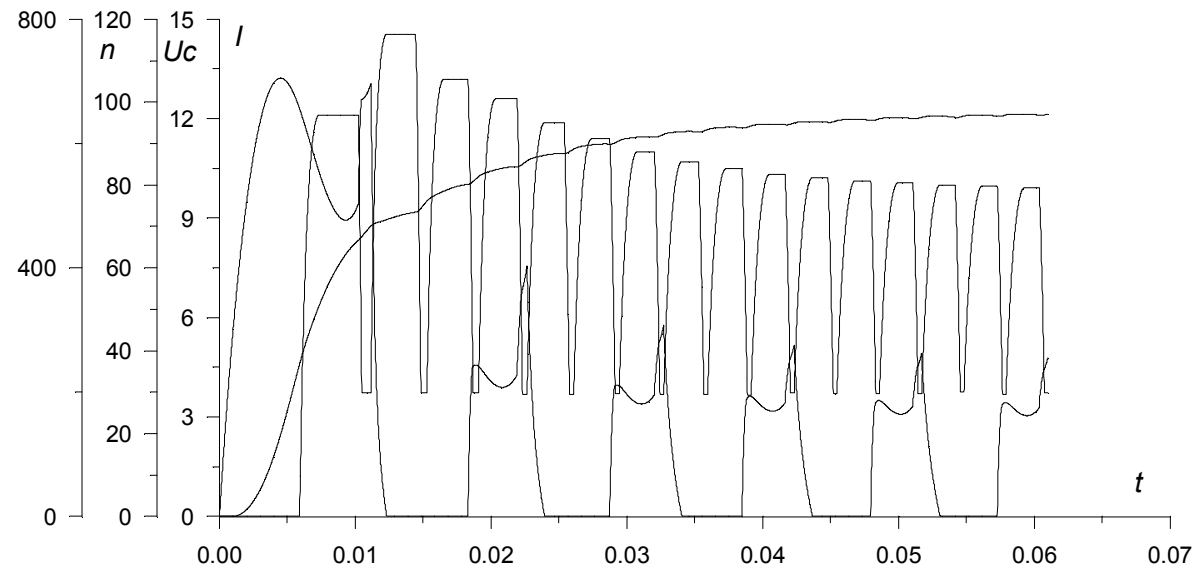

Рис. 7. Пуск ВРД із паралельним $С Н Е$ (розрахунковий струм однієї секиії, напруга конденсатора та швидкість обертання) 
Приклад розрахунку перехідного процесу пуску трисекційного ВРД з СНЕ (розрахунковий струм секції, електромагнітний момент, швидкість обертання) наведено на рис. 8.

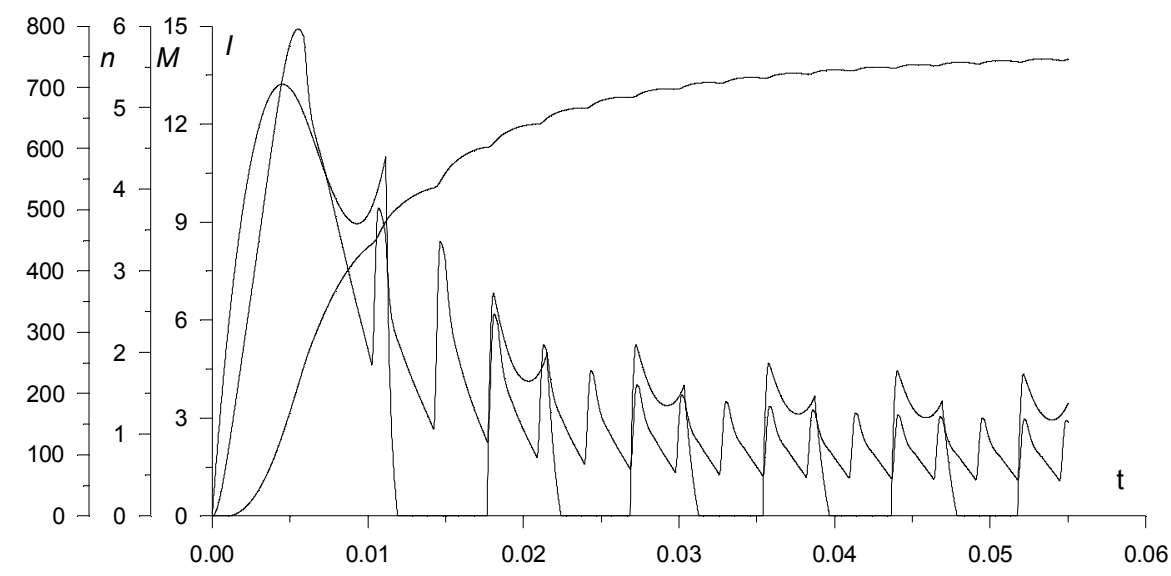

Рис. 8. Струм секиії, електромагнітний момент та швидкість обертання ВРД із СНЕ під час пуску

\section{Висновки}

Використання однопівперіодного комутатора із паралельно під’єднаним нагромаджувальним конденсатором зменшує рівень пульсацій струму і доцільне, зокрема, у разі живлення від автономного джерела обмеженої потужності.

Зіставлення результатів розрахунків із дослідними даними, а саме осцилограм струмів, швидкості обертання і складових втрат для макетних зразків ВРД, показують, що їх похибка в межах 5-6 \%, і свідчать про достатню адекватність математичної моделі.

\section{Перспективи подальших досліджень}

Вентильний реактивний двигун простіший, технологічніший у виготовленні та надійніший, ніж інші відомі електричні двигуни малої потужності. Як показують подані динамічні та статичні характеристики, запропонована математична модель ВРД $є$ доброю базою для розрахунку характеристик таких двигунів.

\section{References}

1. Tkachuk V., Kasha L. Switched reluctance motor in the controlled electric drive, in: Proceedings Conference ISTET'03, vol. II. Warsaw, Poland, pp. 413-416.

2. Patel, S. R., Gandhi, N., Chaithanya, N., Chaudhari, B. N., \& Nirgude, A. (2017). Design and development of switched reluctance motor for electric vehicle application, in: IEEE International Conference on Power Electronics, Drives and Energy Systems, 2016, January 1-6.

3. Husain T., Elrayyah A., Sozer Y., Husain I. Performance Evaluation and Reliability Enhancement of Switched Reluctance Drive System by a Novel Integrated Power Converter, in: IEEE Transactions on Industrial Electronics, vol. 66, No. 5, pp. 3401-3411.

4. Bogusz, P., Korkosz, M., Prokop, J. A three-phase switched reluctance motor for a highspeed drive, in: 13th Selected Issues of Electrical Engineering and Electronics, 2016; Rzeszow; Poland.

5. Tkachuk V. I., Kasha L. V. Switched reluctance motor with serial capacity storage and its mathematical model, in: Proceedings of ISTC UEES-01, Poland, 2001, pp. 953-960.

6. Tkachuk V. I. Electronic commutator with parallel capacity storage for switched reluctance motor, in: Proceedings of ISTC "PEDC-2001", Poland, 2001, pp. 188-198.

7. Maheswari, C., \& Thottungal, R. Analysis and design of a closed loop bridgeless SEPIC converter for SRM drive with reduced ripple current, in: ARPN Journal of Engineering and Applied Sciences, 11(5), 3435-3440.

8. Tkachuk V., Kasha L.. Mathematical Model for M-phases Switched Reluctance Motor, in: Preglad Elektrotechniczny, R 5, No. 2/2007. pp. 84-87.

9. Tkachuk V., Biljakovskyj I., Kasha L. SRM and Its Automated Research System, in: Proceedings of 9th International Workshop "CPEE'08”, Ukraine, 2008, pp. 32-37. 
10. Tkachuk, V., Kasha, L., Shapovalov, I. Switched reluctance motor in the controlled electric drive, in:Proceedings of 7th International Conference on Perspective Technologies and Methods in MEMS Design, 2011, 120-123.

\author{
V. I. Tkachuk \\ Lviv Polytechnic National University, \\ Department of Electromechatronics and Computerized Electromechanical Systems, \\ e-mail: tkachuk@polynet.lviv.ua, \\ I. Ye. Bilyakovskyy \\ Lviv Polytechnic National University, \\ Department of Electromechatronics and Computerized Electromechanical Systems, \\ ibilyakovsky@gmail.com, \\ L. V. Kasha \\ Lviv Polytechnic National University, \\ Department of electromechatronics and computerized electromechanical systems, \\ lidiia.v.kasha@1pnu.ua
}

\title{
SWITCHED RELUCTANCE MOTOR WITH ENERGY CAPASITY STORAGE IN SYSTEM WITH AUTONOMUS LIMITED POWER SUPPLING
}

(C) Tkachuk V. I., Bilyakovskyy I. Ye., Kasha L. V., 2019

The article substantiates the expediency of using a capacitive storage in the circle of an electronic switch to improve the technical and economic performance of the switched reluctance motor. Such electromechanical converter is maximally simplest by design and construction, chip in technology side. It has good performance compared to simplest motor - induction, and, electric drive on the base of switched reluctance motor according to the regulating properties to drives with DC motors, that have unlimited distribution as know.

New electrical schemes oriental on suppling by low voltage and limited power suppling are proposed. Energy buffers are used in this schemes not only protect the power transistors of the switch from the overvoltage phenomenon at the switch-off moment of the section, but also serve as a function of accumulation of energy stored in the magnetic field, which is then used to force the section current in the next section. It is possible to organize control in such schemes of the electronic commutator, when the control signals are formed by the logical multiplication of the signals of the adjacent rotor position sensor.

The given mathematical model are used for investigation and are given in such paper for instantaneous values of a switched reluctance motor with capacity energy buffers and which is the basis for calculation of its characteristics. To solve the problem of finding the moments of switching in problems of this type, we used the method of inverting a nonlinear system of differential equations. The essence of this method in relation to this task is that approximately switching-on or -off any of the power transistors of the electronic commutator, an independent variable accepts switching angle. The investigation results of mechanical and performance characteristics of a brush-less motors with a passive rotor and energy buffer are developed by a computer-aided research system of switched reluctance motor with energy buffers.

Calculation results of dynamic and static characteristics are given in this paper. Its show that the proposed mathematical models are a good base for the calculation of the characteristics of such engines. The results of computer simulation of electromechanical processes are confirmed by experimental studies and show the adequacy of the material model presented in the materials and the feasibility of using such an engine type.

Key words: switched reluctance motor; passive rotor; transistor switches; low power voltage supply; capacity energy storage; mathematical model. 